\title{
Status periodontal pelajar umur 12 - 14 tahun di SMP Negeri 2 Ranoyapo Kabupaten Minahasa Selatan
}

\author{
${ }^{1}$ Grace M. M. Sompie \\ ${ }^{2}$ Christy N. Mintjelungan \\ ${ }^{2}$ Juliatri \\ ${ }^{1}$ Kandidat Skripsi Program Studi Pendidikan Dokter Gigi Fakultas Kedokteran \\ ${ }^{2}$ Program Studi Pendidikan Dokter Gigi Fakultas Kedokteran \\ Universitas Sam Ratulangi Manado \\ Email: gracemirlie28@gmail.com
}

\begin{abstract}
The growth and developmemental process of adolescence to the adult stage is marked by the presence of physiological and hormonal changes as well as mental and mindset maturity. Adolescents should aware of the needs of dental and oral hygiene in order to prevent the occurence of periodontal diseases. This study aimed to obtain the periodontal status of students aged 12-14 years at SMP Negeri 2 Ranoyapo South Minahasa. This was a descriptive study with a cross sectional design. There were 64 students obtained by using total sampling method. Community Periodontal Index of Treatment Needs (CPITN) was evaluated on them. The results showed that of 64 students aged 12-14 years, 8 had (12.5\%) healthy periodontal tissue (Score 0); 3 (4.6\%) had gingival bleeding without calculus (score 1); 44 (68.7\%) had gingival bleeding associated calculus (Score 2); 9 (14.0\%) had periodontal pockets sized 3.5$5.5 \mathrm{~mm}$; and no one had periodontal pocket sized $>5.5 \mathrm{~mm}$. Conclusion: Based on CPITN evaluation, most of the students at SMP Negeri 2 Ranoyapo South Minahasa showed gingival bleeding associated with calculus.
\end{abstract}

Keywords: periodontal status, youth, CPITN

\begin{abstract}
Abstrak: Proses tumbuh kembang dari masa remaja sampai ke tahap dewasa ditandai dengan adanya perubahan fisiologis dan hormonal serta kematangan mental dan pola pikir. Anak remaja seharusnya memiliki kesadaran terhadap kebutuhan kebersihan gigi dan mulut guna untuk mencengah terjadinya penyakit periodontal, karena itu jika anak remaja kurang kesadaran terhadap kebersihan gigi dan mulut akan memiliki resiko terhadap penyakit periodontal. Penelitian ini bertujuan untuk mengetahui status periodontal pelajar umur 12-14 tahun di SMP Negeri 2 Ranoyapo Kabupaten Minahasa Selatan. Jenis penelitian ini ialah deskriptif dengan desain potong lintang. Penelitian ini dilakukan di SMP Negeri 2 Ranoyapo Kabupaten Minahasa Selatan dengan subjek penelitian sebanyak 64 orang yang diperoleh dengan metode total sampling. Community Periodontal Index Treatment Needs (CPITN) dievaluasi pada setiap subyek. Hasil penelitian menunjukkan dari 64 subyek penelitian, skor CPITN tertinggi sebanyak 43 orang $(67,2 \%)$ yang mengalami perdarahan gingiva disertai kalkulus dan skor CPITN terendah yaitu 4 orang $(6,2 \%)$ yang mengalami perdarahan gingiva tidak disertai kalkulus. Simpulan: Penilaian status periodontal dengan CPITN mendapatkan sebagian besar pelajar mengalami perdarahan gingival disertai kalkulus.
\end{abstract}

Kata kunci: status periodontal, remaja, CPITN

Kesehatan gigi dan mulut merupakan bagian integral dari kesehatan umum lainnya. Kesehatan gigi dan mulut yang tidak terpelihara dapat mengganggu fungsi bicara, pengunyahan, rasa percaya diri, serta kesehatan umum sehingga hal ini 
memengaruhi kualitas hidup., ${ }^{1,2}$

World Health Organization (WHO) menetapkan sekolah dan remaja dijadikan sebagai kelompok target yang penting untuk dilakukan pemeriksaan dan promosi kesehatan rongga mulut dan merekomendasikan usia untuk pemeriksaan kesehatan rongga mulut yaitu usia 12-14 tahun., Usia tersebut direkomendasikan sebagai usia untuk pemeriksaan karena gigi tetap yang menjadi gigi indeks Community Periodontal Index Treatment Needs (CPITN) telah bertumbuh seutuhnya. ${ }^{5}$

Hasil Riset Kesehatan Dasar (Riskesdas) 2013 menunjukkan prevalensi penduduk yang memiliki masalah penyakit periodontal di Indonesia sebesar 96,5\% yang menunjukkan bahwa penyakit periodontal menjadi salah satu masalah utama bagi kesehatan gigi dan mulut. ${ }^{6,7}$

Kebersihan gigi dan mulut merupakan faktor yang mendukung terciptanya kesehatan gigi dan mulut termasuk jaringan periodontal. Kurangnya kebersihan gigi dan mulut berisiko terhadap pembentukan kalkulus. ${ }^{8}$ Kalkulus timbul di daerah permukaan gigi yang sulit dibersihkan yang dapat menyebabkan masalah pada jaringan periodontal seperti gingivitis, periodontitis bahkan jika berlangsung lebih lama akan menyebabkan kehilangan gigi. ${ }^{2}$ Riskesdas 2013 juga menunjukkan gingivitis dan periodontitis menjadi penyakit jaringan periodontal yang banyak ditemukan yaitu sebesar 31,6\% di Sulawesi Utara dan $23,4 \%$ di Indonesia. ${ }^{7}$

Pada golongan usia dewasa muda rentan terhadap penyakit periodontal seperti gingivitis dan periodontitis. Hal ini dapat dilihat dari data WHO pada tahun 2010 bahwa usia 15 tahun $48,7 \%$ mengalami gingivitis akibat dari kalkulus. Pada usia ini rentan terhadap kalkulus karena masih banyak remaja yang memiliki kebiasaan buruk sehingga memengaruhi status kesehatan gigi dan mulut dalam hal status periodontal. 4

Berdasarkan latar belakang di atas dan mengingat dampak yang dapat terjadi akibat penyakit periodontal dan juga berdasarkan survei awal yang dilakukan bahwa di sekolah tersebut belum pernah diadakan penelitian mengenai status periodontal pada pelajar, maka peneliti tertarik untuk melakukan penelitian mengenai status periodontal pada pelajar usia 12-14 tahun di SMP Negeri 2 Ranoyapo Kabupaten Minahasa Selatan.

\section{METODE PENELITIAN}

Jenis penelitian ini ialah deskriptif dengan desain potong lintang. Populasi penelitian ini ialah seluruh pelajar di SMP Negeri 2 Ranoyapo Kabupaten Minahasa Selatan berusia 12-14 tahun yang berdasarkan survei awal terdiri dari 176 orang. Sampel penelitian diperoleh dengan menggunakan rumus Slovin sebanyak 64 pelajar berusia 12-14 tahun, terdiri atas 26 laki-laki dan 38 perempuan.

Pemeriksaan dilakukan menggunakan kaca mulut dan probe WHO. Kondisi jaringan periodontal dan distribusi frekuensinya dievaluasi dengan indeks Community Periodontal Index of Treatment Needs (CPITN) dan digambarkan berdasarkan indeks CPITN. ${ }^{10}$ Skor pemeriksaan CPITN yang menunjukkan keadaan jaringan periodontal ialah sebagai berikut: $0=$ sehat; $1=$ perdarahan pada gingiva $; 2=$ kalkulus supra maupun subgingiva; $3=$ poket dangkal $(3,5-5,5 \mathrm{~mm}) ; \quad 4=$ poket dalam $(>5,5 \mathrm{~mm})$.

Penelitian diawali dengan mengisi lembar informed consent. Pemeriksaan dilakukan langsung secara tim di SMP Negeri 2 Ranoyapo. Pemeriksaan dilakukan secara bergilir pada setiap pelajar yang termasuk dalam kriteria inklusi.

\section{HASIL PENELITIAN}

Distribusi subyek penelitian berdasarkan jenis kelamin, usia, status jaringan periodontal dapat dilihat pada Tabel 1-4.

Tabel 1. Distribusi subjek penelitian berdasarkan jenis kelamin

\begin{tabular}{ccc}
\hline Jenis kelamin & n & \% \\
\hline Laki - laki & 26 & 40,6 \\
Perempuan & 38 & 59,4 \\
Total & 64 & 100,0 \\
\hline
\end{tabular}


Tabel 2. Distribusi subjek penelitian berdasarkan usia

\begin{tabular}{ccc}
\hline $\begin{array}{c}\text { Usia } \\
\text { (tahun) }\end{array}$ & n & \% \\
\hline 12 & 21 & 32,8 \\
13 & 33 & 51,6 \\
14 & 10 & 15,6 \\
Total & 64 & 100,0 \\
\hline
\end{tabular}

Tabel 3. Distribusi status jaringan periodontal yang diukur menggunakan CPITN berdasarkan jenis kelamin

\begin{tabular}{ccccc}
\hline & \multicolumn{5}{c}{ Jenis kelamin } \\
Status jaringan periodontal & \multicolumn{2}{c}{ Laki-laki } & \multicolumn{2}{c}{ Perempuan } \\
& $\mathrm{n}$ & $\%$ & $\mathrm{n}$ & $\%$ \\
\hline Sehat & 4 & 15,4 & 4 & 10,5 \\
Perdarahan gingiva tidak disertai kalkulus & 3 & 11,5 & 1 & 2,6 \\
Perdarahan gingiva disertai kalkulus & 16 & 61,6 & 27 & 71,1 \\
Poket periodontal $3,5-5,5 \mathrm{~mm}$ & 3 & 11,5 & 6 & 15,8 \\
Poket periodontal $>5,5 \mathrm{~mm}$ & 0 & 0 & 0 & 0 \\
Total & 26 & 100 & 38 & 100 \\
\hline
\end{tabular}

Tabel 4. Distribusi status jaringan periodontal berdasarkan usia

\begin{tabular}{|c|c|c|c|c|c|c|c|c|c|c|c|c|}
\hline \multirow{3}{*}{$\begin{array}{c}\text { Usia } \\
\text { (tahun) }\end{array}$} & \multicolumn{10}{|c|}{ Skor CPITN } & \multicolumn{2}{|c|}{ Total } \\
\hline & \multicolumn{2}{|c|}{0} & \multicolumn{2}{|c|}{1} & \multicolumn{2}{|c|}{2} & \multicolumn{2}{|c|}{3} & \multicolumn{2}{|c|}{4} & & \\
\hline & $\mathrm{n}$ & $\%$ & $\mathrm{n}$ & $\%$ & $\mathrm{n}$ & $\%$ & $\mathrm{n}$ & $\%$ & $\mathrm{n}$ & $\%$ & $\mathrm{n}$ & $\%$ \\
\hline 12 & 2 & 0,52 & 0 & 0 & 13 & 76,1 & 3 & 14,2 & 0 & 0 & 21 & 100 \\
\hline 13 & 4 & 12,1 & 3 & 9,09 & 23 & 63,6 & 6 & 18,1 & 0 & 0 & 33 & 100 \\
\hline 14 & 2 & 20 & 0 & 0 & 8 & 80 & 0 & 0 & 0 & 0 & 10 & 100 \\
\hline Total & 8 & 12,5 & 3 & 4,7 & 44 & 68,7 & 9 & 14,1 & 0 & 0 & 64 & 100 \\
\hline
\end{tabular}

\section{BAHASAN}

Subjek yang diteliti pada penelitian ini yaitu pelajar SMP Negeri 2 Ranoyapo yang berusia 12-14 tahun dengan jumlah sampel sebanyak 64 orang terdiri dari 26 laki-laki dan 38 perempuan.

Hasil penelitian mengenai status jaringan periodontal berdasarkan pengukuran CPITN menunjukkan bahwa pelajar yang memiliki jaringan periodontal sehat 8 orang $(12,5 \%)$; hal ini sesuai dengan penelitian yang dilakukan Slat et al. ${ }^{5}$ tahun 2013 di SMA Negeri 1 Manado yang menunjukkan 38 orang $(16,8 \%)$ dari 226 subjek penelitian memiliki jaringan periodontal yang sehat.

Hasil penelitian menunjukkan bahwa banyak pelajar yang mengalami perdarahan gingiva disertai kalkulus yaitu 43 orang
$(67,2 \%)$. Hasil penelitian ini sesuai dengan penelitian Gani dan Taufiqurrahman ${ }^{3}$ yang dilakukan pada remaja di Kabupaten Sinjai tahun 2007 yang menunjukkan bahwa $70,3 \%$ subjek penelitian mengalami perdarahan gingiva disertai kalkulus. Alasan tingginya jumlah subjek penelitian yang mengalami perdarahan gingiva disertai kalkulus (skor 2) dapat dihubungkan dengan rendahnya kebersihan rongga mulut. Hasil penelitian yang menunjukkan bahwa perdarahan gingiva disertai kalkulus pada pelajar usia 12-14 tahun sesuai dengan teori yang menyatakan bahwa penyakit periodontal terjadi karena adanya faktor primer berupa iritasi bakteri dan faktor sekunder berupa faktor lokal dan sistemik. Faktor lokal dapat berupa restorasi yang keliru, kavitas karies, 
tumpukan sisa makanan, geligi tiruan yang desainnya tidak baik, alat ortodonti, susunan gigi-geligi yang tidak teratur, kebiasaan bernafas melalui mulut dan merokok, sedangkan faktor sistemik dapat berupa faktor genetik, nutrisi, hormonal dan hematologik (penyakit darah). ${ }^{11}$ Pada pelajar usia 12-14 tahun faktor sistemik yang dapat memengaruhi kondisi jaringan periodontal ialah faktor hormonal. Perubahan hormonal yang berlangsung pada masa pubertas dapat menyebabkan inflamasi yang hebat yang diikuti dengan pembengkakan dan perdarahan gingiva. ${ }^{12}$

Kalkulus merupakan suatu massa yang mengalami kalsifikasi, terbentuk, melekat erat pada permukaan gigi dan objek solid lainnya di dalam mulut misalnya restorasi dan gigi-geligi tiruan. Kalkulus jarang ditemukan pada gigi susu dan tidak sering ditemukan pada gigi permanen anak. ${ }^{13}$ Meskipun demikian, pada anak usia 9 tahun, kalkulus sudah dapat ditemukan pada sebagian besar rongga mulut dan pada hampir seluruh rongga mulut individu dewasa. Berdasarkan hubungannya terhadap margin gingiva, kalkulus dikelompokkan menjadi kalkulus supragingiva dan subgingiva. Kalkulus supragingiva ialah kalkulus yang melekat pada permukaan mahkota gigi mulai dari puncak margin gingiva dan dapat dilihat. ${ }^{14}$

Kalkulus subgingiva ialah kalkulus yang berada di bawah batas margin gingiva, biasanya pada daerah sulkus gingiva dan tidak dapat terlihat pada waktu pemeriksaan, tampak padat dan keras berwarna coklat tua atau hijau kehitamhitaman, konsistensi seperti kepala korek api dan melekat erat ke permukaan gigi. Kalkulus banyak terdapat pada bagian bukal molar rahang atas yang berhadapan dengan duktus Stensen pada bagian lingual gigi depan rahang bawah yang berhadapan dengan duktus Wharton's dan juga pada gigi yang sering tidak digunakan. ${ }^{10}$

Kalkulus supragingiva ialah kalkulus yang melekat pada permukaan mahkota gigi mulai dari pumcak gingival margin dan dapat dilihat. Kalkulus ini berwarna putih kekuningan, konsistensinya keras dan mudah dilepaskan dari permukaan gigi menggunakan scaler. Kalkulus supragingiva yang ditemukan pada remaja dapat disebabkan oleh perilaku yang kurang tepat dalam menjaga kebersihan gigi dan mulut, ini bias saja terjadi akibat kurangnya kesadaran remaja mengenai pentingnya menjaga kesehatan gigi dan mulut. ${ }^{15}$

Hasil penelitian ini menunjukkan bahwa subjek penelitian perempuan yang mengalami perdarahan gingiva disertai kalkulus sebanyak 27 orang $(71,1 \%)$. Hal ini tiak sejalan dengan penelitian yang dilakukan oleh Sanei dan NikbakhtNasrabadi tahun 2005 pada remaja di Iran yang menunjukkan bahwa kalkulus ditemukan lebih banyak pada subjek penelitian laki-laki yaitu $51,2 \% .{ }^{16}$ Hasil penelitian ini juga tidak sesuai dengan penelitian yang dilakukan Nagarajappa et al. ${ }^{17}$ di Udaipur, India (2012) yang menunjukkan bahwa subjek penelitian perempuan demgan status jaringan periodontal sehat lebih banyak dari pada subjek penelitian laki-laki. Jika dilihat pada skor CPITN berdasarkan jenis kelamin terbanyak yang dialami oleh pelajar baik laki-laki maupun perempuan pada penelitian ini sama yaitu perdarahan gingiva disertai kalkulus (skor 2); hal ini menandakan bahwa dalam penelitian ini jenis kelamin tidak terlalu berpengaruh dalam menentukan status jaringan periodontal. Sehat atau tidak sehatnya jaringan periodontal seseorang lebih dipengaruhi oleh keadaan oral hygiene atau kebersihan rongga mulut dan cara memeliharanya.

Hasil penelitian ini menunjukkan bahwa subjek penelitian berdasarkan usia 12, 13, dan 14 tahun memiliki skor tertinggi yang sama. Hal ini sesuai dengan penelitian yang dilakukan Thamrin ${ }^{15}$ tahun 2015 di SMPN 1 Balopa yang menunjukkan untuk umur 12 tahun sebanyak 8 orang $(61,5 \%), 13$ tahun sebanyak 10 orang $(58,8 \%)$ dan 14 tahun sebanyak 4 orang $(57,1 \%)^{15}$

Hasil penelitian mendapatkan bahwa usia 12, 13 dan 14 tahun menunjukkan status periodontal skor tertinggi yaitu perdarahan gingiva disertai kalkulus (skor 
2) sehingga dapat disimpulkan bahwa sehat atau tidaknya jaringan periodontal seseorang tidak dipengaruhi oleh usia melainkan lebih dipengaruhi oleh keadaan oral hygiene atau kebersihan mulut dan cara memeliharanya. ${ }^{18}$

\section{SIMPULAN}

Dari hasil penelitian yang dilakukan pada pelajar berusia 12-14 Tahun di SMP Negeri 2 Ranoyapo dapat disimpulkan bahwa pada penilaian status periodontal dengan skor CPITN sebagian besar pelajar mengalami perdarahan gingival disertai kalkulus.

\section{SARAN}

1. Bagi sekolah: Mengadakan usaha preventif berupa penyuluhan mengenai kesehatan gigi dan mulut, pengetahuan dan perilaku sehat kepada remaja guna mencegah kerusakan jaringan periodontal pada usia muda serta lebih memotivasi dan memperhatikan derajat kebersihan gigi dan mulut siswa melalui programprogram yang ada di sekolah itu sendiri.

2. Bagi Pemerintah: Diharapkan dapat memperhatikan derajat kebersihan gigi dan mulut pada remaja dan menyediakan fasilitas sarana dan prasarana untuk menunjang pelaksaan program kebersihan gigi dan mulut tersebut.

\section{DAFTAR PUSTAKA}

1. Wangsahardja K. Kebutuhan pelayanan kesehatan gigi dan mulut pada masyarakat berpenghasilan rendah. Majalah Ilmiah Kedokteran Gigi. 2007;22(3):90.

2. Petersen PE. The world oral health report 2003. [online] 2003. [cited 2013 July11]. Available from: URL: http://www.who.int/entity/oral_health /media/en/orh_reports03_en.pdf

3. Gani A, Taufiqurrahman. Kebutuhan perawatan periodontal remaja di kabupaten Sinjai tahun 2007. J dentofasial, 2008;7(2) .Hal.132-8.

4. Caroline S. Gambaran faktor demografi, penyakit penyerta dan gaya hidup pada congestive heart failure $(\mathrm{CHF})$ di RSUP Dr. Wahidin Sudirohusodo dan RS. Stella Maris Makassar tahun 2011. Available from: http://repository.unhas.ac.id/handle/1 23456789/385

5. Slat ME, Zuliari K, Suling PL. Gambaran status jaringan periodontal pada pelajar SMA Negeri 1 Manado. [ serial online] 2012. [cited 2014 Dec 12]Available from: URL: http: //ejournal.unsrat.ac.id/index.php/egigi /article/view/3150/2692.

6. Samuel S, Bender IB. The dental pulp biologic considerations in dental procedures (3rd ed). Philadelphia: J.B. Lippincott, 1984; p. 173-7.

7. Riset Kesehatan Dasar 2013. Laporan Nasional. Departemen Kesehatan Republik Indonesia; 2013 [seial online]. Available from URL: http//www.depkes.go.id/resource/dow nload/general/hasil\%20Riskesdas $\% 20$ 2013.pdf

8. Pintauli S, Taizo H. Menuju gigi dan mulut sehat, pencegahan dan pemeliharaan. USS Press. [serial online] 2008 [cited 2013 July 13]. Available from: URL: http://usupress.usu.ac.id/Menuju\%20 Gigi $\% 20$ Gigi $\% 20$ dan $\% 20$ mulut $\% 2 \mathrm{~m}$ ulut $\% 20$ Sehat $\% 20 \_$Pencengahan $\% 20$ Pemeliharaan_Normal_bab\%201.pdf

9. Itjiningsih. Anatomi gigi. Jakarta: EGC, 1991; p. 239.

10. Putri MH, Herijulianti E, Nurjanah $\mathbf{N}$. Ilmu Pencengahan Penyakit Jaringan Keras dan Jaringan Pendukung Gigi. Jakarta: EGC, 2010; p. 25-32, 39, 4345, 47-50, 85-7,150,203-9.

11. Thomas MV. Oral physioteraphy. In: Rose LF, Mealey BL. Genco RJ, Cohen W, editors. Periodontics: Medicine, Surgery and Implants. St. Louise, Missouri: Elsevier Mosby, 2004; p. 376-98, 402.

12. Tungga DM. Hubungan kandungan kapur dalam air minum dengan pembentukan indeks kalkulus pada siswa usia 12-14 tahun di SMP Negeri 2 Soko, Tuman [Tugas akhir]. Malang: Fakultas Kedokteran Universitas Brawijaya; 2011.

13. Pintauli S, Hamada T. Menuju Gigi dan Mulut Sehat Pencegahan dan Pemeliharaan. Medan: Universitas Sumatera Utara. 2009; p.1-6, 15-24, 29-30, 70-84. 
14. Astuti FY. Penelitian Pengaruh Kehamilan Kesehatan Periodontal. Sei Rampah: Universitas Sumatra Utara, 2009; p.13.

15. Thamrin NA. Kebutuhan perawatan periodontal pada remaja SMPN 1 Belopa usia 12-14 tahun di Kabupaten Luwu [Skripsi]. Makassar: Fakultas Kedokteran Gigi Universitas Hasanuddin; 2015.

16. Soetjiningsih. Tumbuh Kembang Remaja dan Permasalahanya. Jakarta: Sagung Seto, 2004; p. 48.
17. Nagarajappa R, Kenchappa M, Ramesh G, Nagarajappa S, Assessment of periodontal status and treatment needs among 12 and 15 years old school children in Udaipur, India. Eur Arch Paediatr Dent. 2012;13(3):132.

18. Perry DA. Plaque control for the periodontal patient. In: Newman, Takei, Klokkevold, Carranza, editors. Carranza's Clinical Periodontology (11th ed). St. Louise, Missouri: Saunders Elsevier, 2006; p. 453. 